\title{
OBITUARY
}

\section{GEORGE PERCY BARGERY}

It is given to few men to become a legend in their lifetime : Bargery was one of these few. With the passing of men like Firth, Guillaume, and Bargery our society would seem to have lost some quality of life which we may perhaps nevel see again. These three names are bracketed on the one score of personality and individuality. Unlike Firth and Guillaume, Bargery was not an academic in the strict sense. The time he spent at the School from 1930 to 1947 was a relatively short period in his career, and, though he was made on his retirement from the staff an Honorary Fellow of the School, in which he had, since 1937, held the title of Reader in Hausa, the School and University were not the main interests of his life. Yet in those 17 years he not only proved himself a wise counsellor anc loyal member of staff (for a time he acted as Head of the Department of Africa) but endeared himself to all, from professors to hall-porters, by the warmth anc radiance of his expansive and all-embracing personality and by the simple goodness of his character. For, above all, Bargery was a man of indomitable faith, courage, and optimism, and a humanitarian in the best and broadest sense. He believed in God and he loved his fellow men. Fully 60 years of ar exceptionally long and active life (he died on 2 August 1966, just two months short of his ninetieth birthday) were spent in unstinting service to God and man

Born at Exeter on 1 October 1876, the youngest of a large family, he was after education in Exeter and London, ordained to the Anglican ministry ir 1900. Almost immediately thereafter he applied to and was accepted by the Church Missionary Society and went out to Northern Nigeria, which was ther still in process of annexation. Bargery was unique in that his work in and for Northern Nigeria spanned the whole period of British rule right up to inde pendence. Of those early days in the country he seldom spoke, and most of his contemporaries have long since died. Time and again he was pressed to writt his memoirs, but always declined, on the ground that few people would believt the things he knew to have happened and he did not intend the ignorant anc prejudiced to call him a liar. One story of him is still current : once, when he was travelling up-country with only one servant and all his worldly goods or the back of a donkey, he got ahead of one of Lugard's advancing columns anc was in danger of running into a hostile emir who was preparing to resist the British. They did not meet, but, if they had, Bargery would doubtless have proved equal to the occasion! For some of the time he had with him-what was rare in those days - a wife, Nina, who shared his life and hardships. They were a devoted couple, and they both loved entertaining: their ' home in the bush ' must have seemed a haven to many a homesick exile.

Ten years later he was back in England, invalided by the Society as unfit for further service in the tropics and with the first of several maladies with which he seemed to enjoy mystifying the doctors throughout his life. He made a complete recovery, was accepted for a post in the Colonial Education Service, which was 


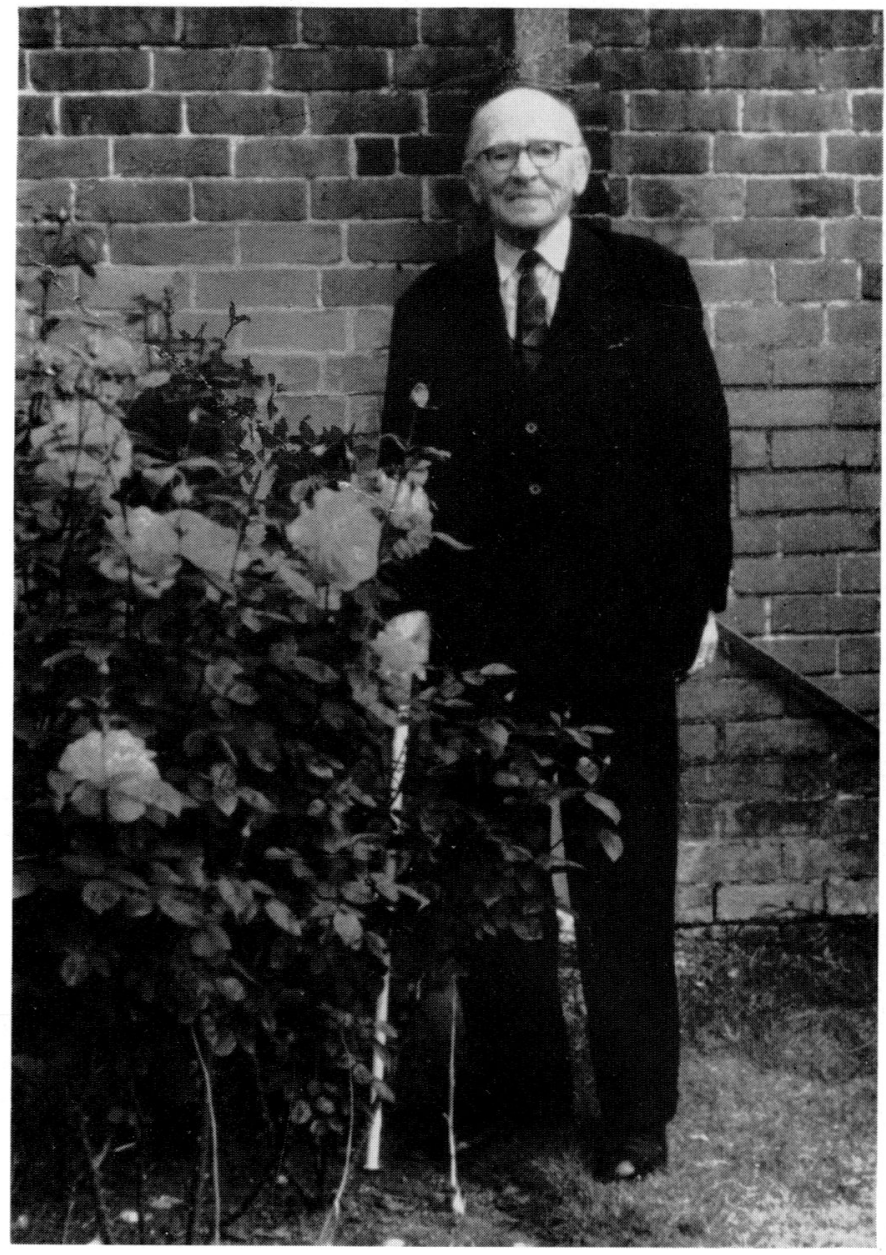

George Percy Bargery

BSOAS. $\mathrm{xxx}_{]}$ 
just starting operations in Northern Nigeria, and in 1912 was back in the country, where he remained until 1930 doing pioneer work among the Tiv, Hausa, and other peoples. I think Bargery himself regarded this period as the happiest and most productive of his life, save that this time his wife could not accompany him. She too had been invalided home in 1910, and did not return : she died in 1932. It was during this period that Bargery, after collaborating with the writer's father in compiling a Hausa phrase-book, began his great work on the Hausa dictionary which was to win him world-wide fame and academic recognition. But few who use the book will know that, after he had collected a mass of material, the bush-house in which he was living caught fire and all was burned. It was typical of Bargery that he wasted no tears over this but immediately started the work again from scratch.

There followed his comparatively placid time at the School, teaching Hausa to missionaries and others, and at the same time active in the ministry of the church in his home-town, first at Sutton and then at Bromley. During these years, his eyes began to trouble him. Yet, at the age of 70, his retirement having been deferred owing to the war, he threw himself with youthful zest into the heavy new teaching and organizational demands made by the post-war ' Devonshire' courses for administrative cadets. But Bargery was never so happy as when he was teaching, and, when he did finally retire from the School in 1947, at the age of 71 , he immediately answered an appeal from the Colonial Office to continue the same work at Cambridge, and later at Oxford, though it meant travelling to and fro from his home in Bromley every week in term time. This continued right up to 1953 . He was then 77 and most of us thought this would mean his final retirement from Hausa, especially as his eyesight was now failing fast. But in 1952 he had lost his second wife, Minnie, a retired headmistress of the CMS girls' school at Onitsha, Eastern Nigeria, whom he had first met on board ship in 1900 and whom he had married in 1940, and Bargery was not a man who relished a solitary life. So it was perhaps no surprise to hear that he was returning to his beloved Northern Nigeria, having accepted an invitation from the British and Foreign Bible Society to advise on a new translation of the Bible in Hausa. There he remained, in Kano, with only short breaks, until 1959--by which time he was 82 -putting all his energies into this work so near his heart, fighting almost word by word to secure a version of the New Testament that would be 'understood of the people', not simply by those versed in 'mission Hausa', and at the same time taking a leading part in the life of the local church. To many, the award of the O.B.E. in 1957 seemed scant and belated recognition of his outstanding services to the country, though Bargery himself was delighted.

But the last seven years of his life, when, after several unsuccessful operations on his eyes, he went almost completely blind, and when he was suffering too from an acute hernia, were the greatest witness to his indomitable character and amazing vitality. Those who saw him during these years, when he was living in Reading, will never forget the impression he made on them. To the 
very last, he was always the same vital, optimistic, interested, intensely individual 'Barge', reading insatiably, first in large print books, then from records, and finally from tapes; full of inquiries about the School and his former colleagues ; reminiscing as racily as ever about his days in Nigeria ; or walking, as erect as ever, the streets of Reading brandishing his white stick about him and becoming a familiar figure to the locals.

Though superficially a contradictory character, basically Bargery was a very simple man, with simple unswerving loyalties and beliefs. A Devonian, who would have found a perfect setting in an Eden Phillpotts novel, he retained all his life a delightful Devonshire brogue, not least when he spoke Hausa! He had much of the countryman in his make-up, which helped to put him en rapport with the countryfolk of Nigeria, among whom he spent so much of his life. He was intensely practical, forthright, and down-to-earth, a stickler for order and punctuality, a hater of cant and humbug, and on moral issues uncompromising. It has been said of him that 'for him everything in life was either black or white - there were no greys'. He always called a spade a spade-often a good deal more. His manner of speech was a fine example of the art of hyperbole, and he made no attempt to hide his emotions in any company. His sense of humour was immense, earthy, and sometimes bordering on the macabre. Every story he told-they were legion, and he loved telling and retelling them-was relived and dramatized, and he would end up with tears of laughter streaming down his mobile face, his deep-throated chuckles reverberating round the Common Room. Yet his letters, written in a characteristically bold and flourishing hand with much pressure of the pen and the lines running aslant the page, were brief and to the point, and his sermons never lasted more than 15 minutes, though he would spend many hours in their preparation. His comments on people were often pungent, but never unkind, and no man could laugh at himself more. Many of the best stories that were current about him in Nigeria he would himself confirm, as for instance that, when he returned to England in 1930 to complete the final stages of his dictionary, he applied to the Colonial Office for ' bush allowance' on the ground that he had not been given furnished quarters in London.

He was indeed a very shrewd man who had a strong sense of the value of money where expenditure on himself was concerned. But, where others were concerned, he was generous to a fault, and he loved to entertain his many friends. A teetotaller all his life, yet he relished good food, was something of a dandy in his dress, and for many years of his life was never without a pipe of native Nigerian tobacco, which he had learned to cure himself ; but he gave up smoking directly he felt that he should.

Few perhaps were aware that Bargery had had a medical, as well as a missionary, training, though he never qualified as a doctor, and he had a passion for clinical and anatomical details, which came out, not only in his stories, but also in his dictionary. He was very proud of his medical knowledge, and it was in this sphere that he was most critical of the mistranslations of others. He 
was, indeed, quite brutal at times in his comments on the work of other Hausa scholars (though not on themselves), as those who have seen his marginal comments (he was an inveterate commentator) on the first draft of the new Hausa Bible, which had been done before he arrived on the scene, can testify.

The Hausas have a saying Labarin zuciya a tambayi fuska 'For news of the heart ask the face'. It was certainly true of Bargery: the squareness of his jaw and the firm set of his mouth, topped by those twinkling eyes and Puckish eyebrows, well expressed the character of the man.

But what of Bargery the scholar? He was not a linguist nor an Africanist in the modern scientific sense. A language to Bargery was something that you listened to and spoke as a means of communication, only later perhaps to be studied analytically and systematized, if you had the time and inclination. $\mathrm{He}$ had had no linguistic training, nor a particularly distinguished scholastic career, and his well-known and unparalleled command of Hausa, which earned him the local title Sarkin Hausa ' King of Hausa ' that has been inscribed in the Book of Remembrance where his ashes lie, was largely intuitive. To a man like Bargery, who so loved his fellow men, it would have been inconceivable not to learn to speak fluently the language of those he lived and worked amongst; and he just absorbed Hausa - as he had also done Tiv-as it were, through the pores. He was, however, blessed with an acute ear, which enabled him to detect with accuracy the relative musical pitch of the syllables in any word he heard. This he faithfully recorded in working on his dictionary, every word being tested out for its tones with a number of informants; nothing was assumed. The tone-patterns that emerged were only much later systematized, as notably with the verbal system, the paradigms of which he was the first to present clearly and comprehensively. To him the tone-pattern of a Hausa word was the most significant thing about it. He would whistle tone-patterns to prompt a student, and when occasionally he was stumped for a word-and he remembered to his death almost every word he had recorded in his dictionaryhe could generally give you its tone-pattern.

Mistrusting all theory about language, Bargery's approach was cautious, pragmatic, and empirical, though once a fact was proven to his satisfaction it then became dogma to him. His invariable answer to some problem or point raised by another was ' Ask a Hausa '. Anyone confronting him with an alleged new Hausa word or meaning would be asked 'Where did you hear it ?' ; when told ' $\mathrm{Oh}$, from a Hausa in Kano market yesterday', he would rejoin with 'Show me a hundred, no two hundred, Hausas who use the word, and I'll believe you'.

These qualities and limitations are manifested in his dictionary. He excelled in the definition of concrete terms, especially anything to do with food, dress, parts of the body, and diseases, though occasionally he gives undue prominence to non-essential features. He was much less happy with abstract terms, many of which he tended to misequate with one another, and some of the commonest words of the language he did not bother to treat in any detail at all. His listing 
together, however, of synonyms and near-synonyms, e.g. all the words for 'fool' and for 'meddling', was a most felicitous idea seldom followed by lexicographers and so was his listing of all the names for varieties of guinea-corn and kola-nut, and all the colour terms applied to horses, under the words for 'guinea-corn', 'kola-nut', and 'horse' respectively. His dictionary is also invaluable for the number of dialectal variant forms it records, especially those from the French area of Niger, where he made a long stay, and the dictionary's deficiency in forms and words from the north-western areas of Nigeria-a deficiency which he always regretted--was no fault of his, for he was precluded from on the spot researches. His arrangement of words, however, is in many respects unsystematic-derivatives are seldom cited under their parent words and there is a lack of cross-referencing-and he left much of the theoretical part of the introduction to be written by Westermann.

It may seem strange to us now, with our extended knowledge of the language, that, having pioneered and discovered so much in Hausa, Bargery did not pursue his research further into the field of correlating and classifying words. But he was not interested in the rather abstract phonology and morphology that this would have involved, a field which he was content to leave to his successors.

Bargery in fact was of too extrovert and sociable a temperament to be happy for long just doing research. The compilation of his dictionary, which took him 14 years of his life, must have been in many ways a tedious labour which he undertook largely because he felt it was his duty to do it, and because he saw the immense practical benefits that would accrue from it. He was always a practical man, and nowhere is this better shown than in his detailed stipulations concerning the typography and the quality of the paper on which he wanted it printed. He had begun the dictionary by giving a Hausa malam a twopenny exercise-book and telling him to write down all the words he knew. He ended it with a collection of ' 52,000 words', as he would proudly reiterate, and a book that it was considered justified the cost of complete resetting for a new edition soon after the war. It never, I think, occurred to him to question what was meant by a ' word'.

But the real joy to Bargery was to operate the Hausa language, and secondly to teach others how to do so and to inspire them with something of his own feeling for it. Of these two activities he never tired. He loved to listen to or to tell a Hausa story, constantly reminding his students how he himself first felt himself en rapport with the Hausas when he learned one of their stories by heart and repeated it to an enraptured audience. His lessons were never formal : after half an hour or so of grammatical instruction and pronunciation drill they nearly always ended with a story. His teaching of grammar was sound and practical, if a little oversimplified, and he was particularly encouraging to the less intellectually gifted student. Much of his teaching was embodied in a cyclostyled course he brought out for the post-war cadets, copies of which soon acquired premium value in Nigeria ; unfortunately it was never published. His teaching did not 
go very far into the deeper and finer points of the language, especially in the field of syntax. These he himself seemed to have acquired instinctively and uninquiringly and then to reproduce unerringly. His knowledge of proverbs and idioms of all sorts was prodigious, for he had a remarkable memory : in this connexion, it is said that he never used a prayer-book when taking a service, he knew all the prayers and collects by heart. He wrote a good deal in Hausa at one time and another, and was a master of translation. The New Testament, which was all he was able to finalize of the new Bible in Hausa before he retired (he longed to do the Psalms in Hausa poetry) must rank alongside the best original works of Hausa literature, besides bringing to bilinguals new understanding of the meaning of the Authorized Version. It was characteristic of Bargery that he insisted on having non-Christian Hausas to collaborate in this.

In fact, if one is to select one precept above all others that he impressed upon his students, it is the truism that the Hausa language is what a Hausa speaks and that, if one hopes ever to speak like a Hausa, one must listen and listen again and again. It is true that he tended in his latter days-like so many others-to become rather conservative and normative about the language, taking but little apparent interest in most of its modern literature and scornfully rejecting many borrowed neologisms as 'pure English'. But he was not inflexible, and on his return from Kano the last time he himself conceded that the usage of certain words had changed since ' his day'.

But Bargery will be best remembered as a great lover of Nigeria, and of all peoples and things Nigerian - of the Tiv as much as of the Hausa (how cross he got if you called them ' Tiv'), and all its other peoples too-Christian, Muslim, and pagan alike. To him they were all 'brothers and sisters in God', and he accorded them that respect for their mutunci (human dignity) which so endeared him to them, whilst at the same time he was never blind to, and often vocal about, their mutuntaka (' human nature with its shortcomings and frailties' is his own characteristic gloss). No European had a finer sense of African values and African etiquette-it appalled him that any fundamentalist should have conceived of a literal rendering of the first word in 'Woman, behold thy son'. Of his white colleagues he was more critical. Where his principles were at stake, he was no respecter of persons, and history could record many a fight with superiors both in mission and government service, which he usually won. Compromise and expediency were foreign to his vocabulary. Yet in lesser matters he was the soul of tact, and, once his respect and affection had been won, there was no more loyal or kinder friend. His tender care and medical knowledge and skill saved the lives of more than one European as well as of many Nigerians. He loved at all times to meet and entertain Nigerians, and he remained to the end deeply concerned about the future of their country.

He was, too, a very patriotic Englishman, with strong feelings about ' $\mathrm{King}$ and country'. He was delighted to be chosen to act as interpreter to the then Prince of Wales during the latter's visit to Nigeria in 1925, and as proud in 1937 
to have the degree of D.Lit. conferred on him by the Chancellor of the University of London at the same time as Queen Elizabeth received the D.Lit. as to receive his O.B.E. from Queen Elizabeth II in person in 1957.

Bargery was certainly neither a typical don, nor a typical civil servant, nor yet a typical clergyman or missionary. But he most assuredly was a man, and a giant among men. Of him it can be truly said, Homo sum: humani nihil a me alienum puto.

F. W. PARSONS 